Transactions of the American Fisheries Society, Vol. 115, No. 2, 1986, pp.314-321 DOI: 10.1577/1548-8659(1986)115<314:HSBSBI >2.0.CO;2

ISSN: $1548-8659$

http://afs.allenpress.com/perlserv/?request=get-archive http://afs.allenpress.com/archive/1548-8659/115/2/pdf/i1548-8659-115-2-314.pdf (C) 1986 American Fisheries Society. All rights reserved. 


\title{
Habitat Selection by Smallmouth Bass in Response to Physical Characteristics of a Simulated Stream
}

\author{
Carolyn W. Sechnick ${ }^{1}$ and Robert F. Carline ${ }^{2}$ \\ Ohio Cooperative Fishery Research Unit ${ }^{3}$ \\ Roy A. Stein ANd Edward T. Rankin ${ }^{4}$ \\ Department of Zoology \\ The Ohio State University, Columbus, Ohio 43210, USA
}

\begin{abstract}
Juvenile (14-16 cm total length) and adult (24-26 cm) smallmouth bass Micropterus dolomieui were studied in a laboratory stream tank to determine the influence of light, current velocity, substrate, and cover on habitat selection. These factors were varied singly and in combination for ranges of 30-4,000 lx light intensity; 1-47 and $0-20 \mathrm{~cm} / \mathrm{s}$ current; substrates of sand $(1 \mathrm{~mm})$, gravel $(15-40 \mathrm{~mm})$, boulders with cobble filler $(250 \mathrm{~mm}$ with $50-100 \mathrm{~mm})$, and boulders with cobble removed; and three types of clear and opaque covers. Fish exhibited strong preferences for slow current $(<10 \mathrm{~cm} / \mathrm{s})$, low light $(<300 \mathrm{~lx})$, and cover that provided slow current and low light. Substrate was only important when fish could get into the interstices. Juveniles selected slightly slower current speeds and lower light intensities than adults, but were similar in all other respects.
\end{abstract}

Within the geographic range of a fish species, availability of preferred habitat may explain variation in fish densities (Sale 1972; Hunt 1976; DeVore and White 1978). Habitat preferences are influenced by biotic and abiotic factors. Important in habitat selection by fishes (Butler and Hawthorne 1968; Moyle and Vondracek 1985), abiotic factors may be used to assess the quality of a given area or they may be strongly correlated with biotic factors such as food and protection from predators.

Because smallmouth bass are important sportfish, their physical habitat requirements have been quantified in a general way. In flowing waters they inhabit clear-water streams with moderate to high gradients, rocky substrates, and pool-riffle combinations (Hubbs and Bailey 1938; Reynolds 1965; Coble 1975). Habitat choice by adult smallmouth bass has been examined in the field (Munther 1970; Paragamian and Coble 1975; Probst et al. 1984)

\footnotetext{
${ }^{1}$ Present address: Fullersburg Woods Environmental Center, 3609 Spring Road, Oakbrook, Illinois 60521, USA.

${ }^{2}$ Present address: Pennsylvania Cooperative Fish and Wildlife Research Unit, The Pennsylvania State University, University Park, Pennsylvania 16802, USA.

${ }^{3}$ The unit is sponsored jointly by the U.S. Fish and Wildlife Service, Ohio Department of Natural Resources, and The Ohio State University.

${ }^{4}$ Present address: Ohio Environmental Protection Agency, 1030 King Avenue, Columbus, Ohio 43212, USA.
}

and in the laboratory with juveniles (Haines and Butler 1969; Reynolds and Casterlin 1976). Physical variables that appear to influence habitat choice include light, substrate, current velocity, and cover. In these studies, however, physical variables were not measured at the precise position of the fish, nor were all variables examined simultaneously. The functions of physical structure, termed cover, that attract fish were not examined, and adults and juveniles usually were not tested in the same study. To remedy these deficiencies, we use a behavioral approach in a laboratory stream tank to determine how these four abiotic factors (light, current velocity, substrate, and cover) influence habitat choice by juvenile and adult smallmouth bass. Results from our laboratory study were used as working hypotheses in Rankin's (1986, this issue) field study of smallmouth bass habitat selection.

\section{Methods}

Experiments were conducted in a rectangular stream tank, $4.6 \times 1.8 \times 1.2 \mathrm{~m}$ deep. Three glass windows in the outside wall of each side of the tank enabled us to make observations. The tank was divided lengthwise into two identical channels by a partial wall open at each end to allow water circulation (Sechnick 1981). Current was created by two paddlewheels, powered by $373-W$ adjustable-speed motors, located in opposite corners of the tank (separated from each channel by $6-\mathrm{mm}$ mesh screens). To reduce turbulence, we placed 
baffles of plastic pipe $(15 \times 7.5 \mathrm{~cm}$ in diameter $)$ in front of the paddlewheels; 6-mm-mesh screens separated the baffles from the experimental area. Each experimental channel was $3.0 \times 0.9 \mathrm{~m}$ and water depth was $40 \mathrm{~cm}$. Incandescent light (five bulbs $/ \mathrm{m}$ ), attached to reflectors over each channel of the stream tank, provided artificial lighting. Numbers and wattages of bulbs were varied to modify light intensities for each experiment. Onoff timers coupled with slow-on, slow-off dimmers (to simulate dawn and dusk) approximated a summer photoperiod of $16 \mathrm{~h}$ light : $8 \mathrm{~h}$ darkness. The stream tank and 12 holding aquaria (120-200 L) were enclosed in a light-controlled room. Observation areas were enclosed with black curtains to keep observers in a dark background and window screens were placed on viewing windows to prevent fish from detecting most movement by observers.

To facilitate quantifications of habitat, we measured light and current in the stream tank at 20$\mathrm{cm}$ intervals along its width, length, and depth. Downwelling light was measured with an underwater photometer (Tsurumi-Seikikosaku-Sho Simple Submarine Illuminance Meter ${ }^{5}$ ) immediately beneath the water surface and at the bottom. Current velocity was measured with a MarshMcBirney Model 523 electromagnetic current meter (10-mm-diameter probe). A computer program interpolated the light and current measurements and computed average velocity and light levels for each 10-cm cube in the stream tank. At each observation, the position of the fish was quantified by the grid coordinates $(X, Y$, and $Z$ ) of the cube in which its head was located. From these coordinates, current speed, light intensity, substrate, and cover could then be determined for each position occupied by a fish during an experiment.

Experimental protocol. -Juvenile $(14-16 \mathrm{~cm}$, total length) and adult (24-26 cm) smallmouth bass were electroshocked from the Olentangy River north of Columbus, Ohio, and from the Kokosing River near Millwood, Ohio. Fish were held in standing-water aquaria at least 2 weeks and fed regularly before experiments began.

The basic experiment included $3 \mathrm{~d}$ of acclimation in the stream tank and $3 \mathrm{~d}$ of observations. Observations were made seven times during the day: dawn, dusk, and every $3 \mathrm{~h}$ between these, beginning $1 \mathrm{~h}$ after dawn. During each observa-

\footnotetext{
${ }^{5}$ Reference to trade names does not imply endorsement by the U.S. Fish and Wildlife Service.
}

tion, fish were assigned to grid coordinates every $30 \mathrm{~s}$ for $15 \mathrm{~min}$ (30 observations). Only one fish was tested per channel per experiment. Fish were fed $5 \%$ of their body weight of beef heart at 1530 hours each day. Variations from this basic protocol are noted in Table 1 and discussed in the methods for each experiment.

Four variables were tested: light, current velocity, substrate, and cover. Three lighting conditions were used: a light gradient of 30-4,000 lx with the dark end adjacent to the paddlewheel (upstream), a reversed gradient (30-4,000 lx) with the light end adjacent to the paddlewheel, and a uniform low light intensity $(50-250 \mathrm{~lx})$. In all tests, edges and lower levels of the tank were darker than central and upper areas (Sechnick 1981).

In preliminary light-selection experiments, there was no water current. In the other experiments the current was slow (range: $0-20 \mathrm{~cm} / \mathrm{s}$ ) or fast (1-47 $\mathrm{cm} / \mathrm{s})$. In each test, paddlewheels were set to provide maximum speeds at the center surface of the tank, $20 \mathrm{~cm}$ from the upstream edge of the observation area. Current velocity varied with depth and position in the tank; current speeds were generally slower at the edges than at the center.

Four substrates were used: sand $(1 \mathrm{~mm})$, gravel $(15-40 \mathrm{~mm})$, boulders $(250 \mathrm{~mm})$ with cobble filler $(50-100 \mathrm{~mm})$ in the interstices, and boulders without the cobble filler.

We used clear and opaque covers of three types: square, flat plexiglass plates $(30 \times 30 \mathrm{~cm})$ at the surface and at a depth of $20 \mathrm{~cm}$ (middepth), and an open-ended box (three sides with a square top, $30 \times 30 \times 20 \mathrm{~cm}$ ) placed on the bottom with the open end facing downstream.

We used a $\chi^{2}$ test to compare the frequency of use of a habitat with the expected frequency of use based on the proportional distribution of available habitats throughout the tank. Treating each of the 30 observations within each $15-\mathrm{min}$ period as an independent sample could seriously inflate significance levels and would be a case of pseudoreplication (Hurlbert 1984). Therefore, only datum from each 15-min observation session was considered an independent sample. Frequencies of use for a given habitat condition were reduced by a factor of 30 (number of subsamples within 15-min observation period), providing a conservative test of significance. We used $\chi^{2}$ contingency tables to determine whether use of habitats was independent of individual fish among juveniles and adults. Medians used in analysis of cover selection were calculated with Walsh averages (Hollander and Wolfe 1973). 
TABLE 1. -Summary of conditions for stream-tank selection experiments with smallmouth bass.

\begin{tabular}{|c|c|c|c|c|c|c|c|}
\hline \multirow{2}{*}{$\begin{array}{l}\text { Experi- } \\
\text { ment } \\
\text { number }\end{array}$} & \multirow{2}{*}{$\begin{array}{c}\text { Sample } \\
\text { size } \\
\text { (juvenile/ } \\
\text { adult) }\end{array}$} & \multicolumn{2}{|c|}{ Time (d) } & \multirow{2}{*}{$\begin{array}{c}\text { Obser- } \\
\text { vations } \\
\text { per daya }\end{array}$} & \multicolumn{3}{|c|}{ Experimental conditions } \\
\hline & & $\begin{array}{l}\text { Acclima- } \\
\text { tion }\end{array}$ & $\begin{array}{c}\text { Experi- } \\
\text { ment }\end{array}$ & & $\begin{array}{c}\text { Light }^{b} \\
(1 \mathrm{x})\end{array}$ & $\begin{array}{c}\text { Current } \\
(\mathrm{cm} / \mathrm{s})\end{array}$ & Substrate $^{c}$ \\
\hline \multicolumn{8}{|c|}{ Light selection } \\
\hline 1 & $2 / 2$ & 2 & 3 & 7 & Gradient $(30-4,000)$ & 0 & Gravel \\
\hline 2 & $1 / 1$ & 2 & 3 & 7 & Gradient $(4,000-30)$ & 0 & Gravel \\
\hline 3 & $1 / 1$ & 2 & 1 & 7 & Gradient $(30-4,000)$ & $0-20$ & Gravel \\
\hline 4 & $1 / 1$ & 2 & 1 & 7 & Gradient $(4,000-30)$ & $0-20$ & Gravel \\
\hline 5 & $1 / 1$ & 2 & 1 & 7 & Gradient $(30-4,000)$ & $1-47$ & Gravel \\
\hline 6 & $1 / 1$ & 2 & 1 & 7 & Gradient $(4,000-30)$ & $1-47$ & Gravel \\
\hline \multicolumn{8}{|c|}{ Current selection } \\
\hline 7 & $5 / 4$ & 3 & 3 & 8 & Low range $(50-250)$ & $1-47$ & Gravel \\
\hline 8 & $2 / 3$ & 3 & 3 & 8 & Low range $(50-250)$ & $0-20$ & Gravel \\
\hline \multicolumn{8}{|c|}{ Substrate selection } \\
\hline 9 & $3 / 3$ & 3 & 3 & 8 & Low range $(50-250)$ & $0-20$ & Sand, gravel \\
\hline 10 & $2 / 4$ & 3 & 3 & 4 & Low range $(50-250)$ & $0-20$ & $\begin{array}{l}\text { Sand, boulders, } \\
\text { cobble }\end{array}$ \\
\hline 11 & $0 / 4$ & 3 & 3 & 4 & Low range $(50-250)$ & $0-20$ & Sand, boulders \\
\hline \multicolumn{8}{|c|}{ Cover selection } \\
\hline 12 & $2 / 2$ & $3,1^{d}$ & 1 & 8 & Low range $(50-250)$ & $1-47$ & Gravel \\
\hline 13 & $2 / 2$ & 3,1 & 1 & 8 & Low range $(50-250)$ & $1-47$ & Gravel \\
\hline 14 & $2 / 2$ & 1 & 1 & 8 & Low range $(50-250)$ & $1-47$ & Gravel \\
\hline 15 & $2 / 2$ & 1 & 1 & 8 & Low range $(50-250)$ & $1-47$ & Gravel \\
\hline 16 & $3 / 4$ & 3,1 & 1 & 8 & Low range (50-250) & $1-47$ & Gravel \\
\hline 17 & $4 / 4$ & 3,1 & 1 & 8 & Low range $(50-250)$ & $1-47$ & Gravel \\
\hline
\end{tabular}

${ }^{\text {a }}$ Seven observations per day (hours after dawn): dawn, 1, 4, 7, 10,14, dusk; eight observations per day: hour 15 was added; four observations per day: dawn, dusk, plus two randomly chosen hours.

${ }^{b}$ In the gradient, the left number was the upstream intensity.

c For the substrate selection experiments, either substrate could be upstream. Substrate diameters: sand, $1 \mathrm{~mm}$; gravel, 15-40 $\mathrm{mm}$; cobble, $50-100 \mathrm{~mm}$; boulders, $250 \mathrm{~mm}$.

d Fish were acclimated for $3 \mathrm{~d}$ before the experiment, then $1 \mathrm{~d}$ between cover changes.

Tank bias. - In preliminary light experiments without current, smallmouth bass used upstream areas of the tank (i.e., immediately downstream of paddlewheels) more frequently, whether or not these areas were in the dark portion of the light gradients. When low light intensities were upstream, juveniles and adults selected light intensities between 30 and $100 \mathrm{~lx}$ more than $70 \%$ of the time; intensities of up to 4,000 lx were available. Fish, however, were also in upstream positions when light intensity was high upstream, but because they preferred the edges and bottom of the tank they were still in areas of fairly low intensity (adults less than 900 lx; juveniles less than $4001 \mathrm{x}$ ). It was evident, however, that there was a tank bias for the upstream portion of the stream tank. Thereafter, light-selection experiments were run with current maintained in the stream tank. Current eliminated tank bias in these experiments as evidenced by definite shifts in fish positions with reversal of the light gradient. Occasional attraction by smallmouth bass to reflections in observation windows and attraction to corners noted in light experiments 3 to 6 were eliminated in subsequent current, substrate, and cover experiments by covering the inside of windows with 6-mm-mesh nylon screening and blocking upstream corners with small-mesh screening.

\section{Light Selection}

Light selection experiments were run with slow current (experiments 3 and 4, Table 1 ) or fast current (experiments 5 and 6 ) to simulate a natural stream. The light gradient in one channel placed the brighter end upstream and the other channel had the reverse gradient. One juvenile or one adult was placed into the tank and acclimated for $2 \mathrm{~d}$, tested for $1 \mathrm{~d}$, transferred to the other channel, acclimated for $1 \mathrm{~d}$, and retested.

The juvenile smallmouth bass strongly selected light intensities less than $100 \mathrm{~lx}$ in each channel at slow (Figure 1) and fast current velocities $(P<$ 0.01 ). The adult generally selected light intensities of less than $300 \mathrm{~lx}$; however, selection was not significant (Figure 1). The most frequently selected range of light intensities, 50-250 lx, was used in the remainder of the experiments.

The juvenile in this experiment and those in 


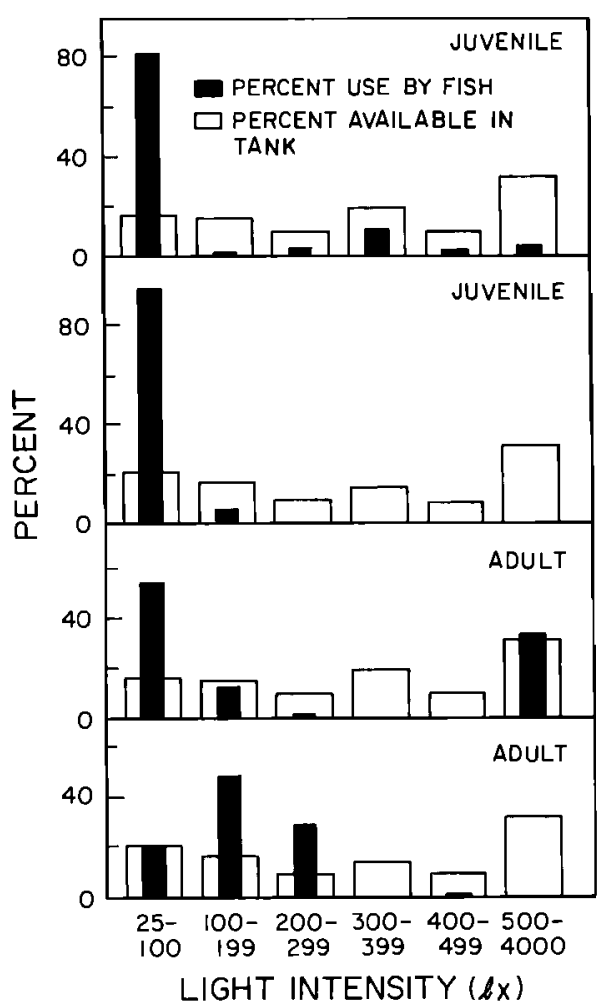

Figure 1.-Light selection by smallmouth bass in light gradients at slow current velocity in a laboratory stream tank. Solid bars represent percent time a fish spent at different light intensities whereas open bars represent light intensities available in the tank. Panels 1 and 3 (from top) represent experiment 3 (high light intensity downstream); panels 2 and 4 represent experiment 4 (high intensity upstream).

subsequent experiments selected the bottom 10 $\mathrm{cm}$ of the water column. The adult in this experiment selected the 10-20-cm depth, whereas adults in subsequent experiments selected the bottom 10 $\mathrm{cm}$. Both adults and juveniles generally oriented into the current except when water velocities at their locations were near zero; then, they oriented about equally in up- and downstream directions.

\section{Current Selection}

Constant light levels (range: 50-250 lx) were used with both fast- (experiment 7 , Table 1 ) and slow- (experiment 8 ) current experiments; the same current regimes were used in later experiments. An observation was added an hour before dusk to determine whether movement increased then.

Whether maximum currents were 20 or $47 \mathrm{~cm} / \mathrm{s}$, both juveniles and adults, with one exception, preferentially selected velocities of $10 \mathrm{~cm} / \mathrm{s}$ or less

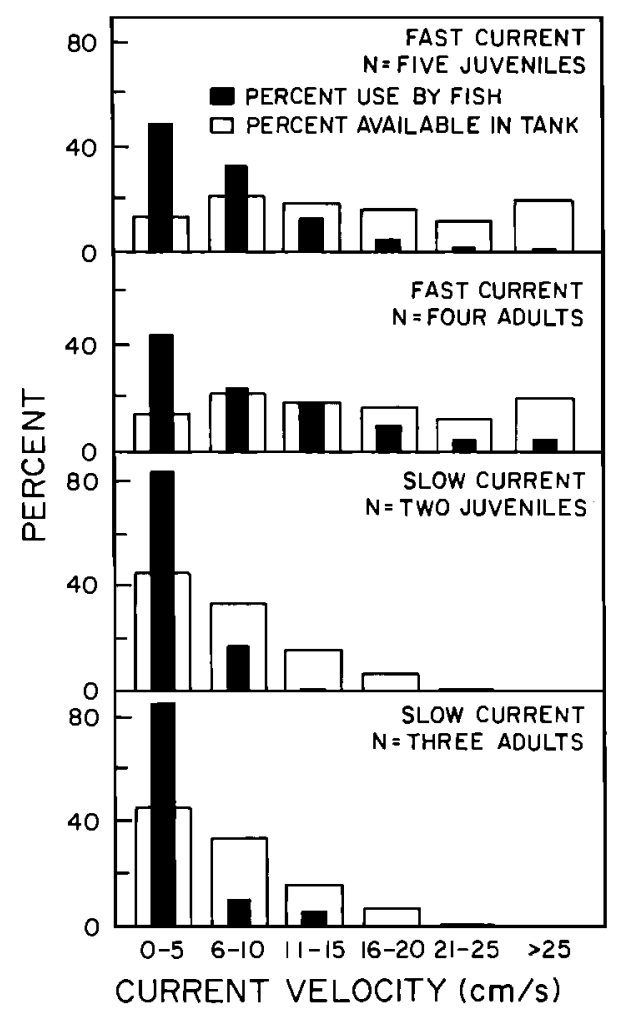

Figure 2.-Current selection by smallmouth bass in slow and fast current velocities at preferred light intensities (experiments 7 and 8) in a laboratory stream tank. Solid bars represent median percent time spent by smallmouth bass at a current velocity whereas open bars represent current velocities available in the tank. Although individual fish varied significantly $(P<0.05)$ in use of current speeds (except adults in slow current), the range of variation was only several $\mathrm{cm} / \mathrm{s}$.

(Figure 2; $P<0.05$ ). Selectivity by both groups was strongest under the low-velocity regime. Adults spent slightly more time in faster currents than juveniles in both tests; however, the variability among individuals was significant $(P<0.05)$, precluding statistical comparisons. The variation in current preferences among individuals, however, was only over the range of a few centimeters per second.

\section{Substrate Selection}

In experiments 9-11 (Table 1), we determined whether or not smallmouth bass selected a substrate size when their preferred current speed and light intensities were available. Sand $(1 \mathrm{~mm})$ was tested against gravel $(15-40 \mathrm{~mm})$ and against boulders $(250 \mathrm{~mm})$ with and without cobble filler $(50$ $100 \mathrm{~mm}$ ). Substrates to be compared covered op- 


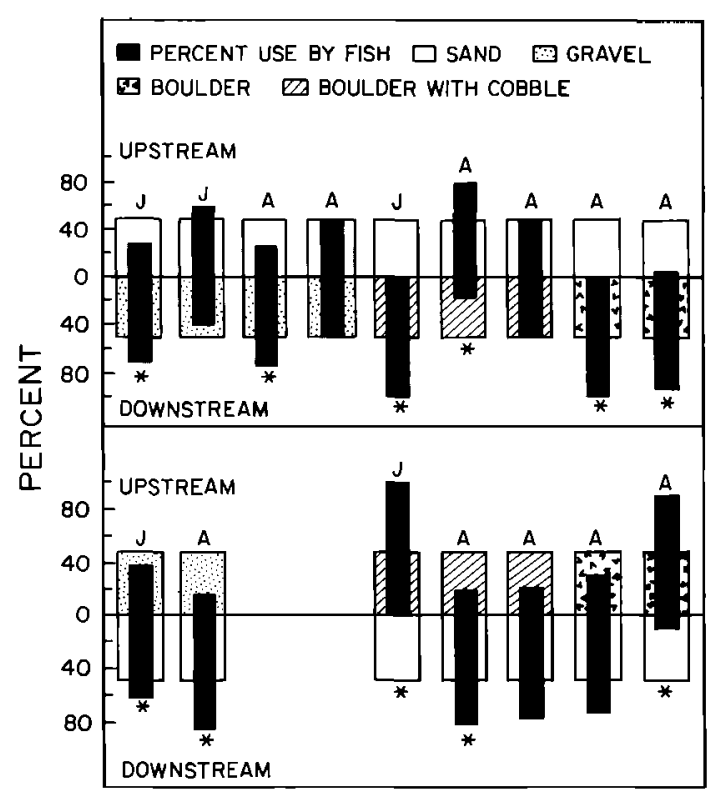

FIGURE 3.-Substrate selection by individual juvenile (J) and adult (A) smallmouth bass when given equal amounts of sand and (1) gravel, (2) boulder, or (3) boulder with cobble substrates at preferred current speed and light intensity in a laboratory stream tank. Upper panel represents experiments with sand upstream; lower panel with sand downstream. Asterisks indicate substrate preference at $P<0.05$.

posite ends of each tank channel; each substrate was upstream in one channel and downstream in the other. Preferred light (50-250 lx) and current $(0-20 \mathrm{~cm} / \mathrm{s})$ regimes were used. In experiments 10 and 11 , dawn and dusk observations were conducted each day, in addition to two other observations chosen at random without replacement from the other six daylight observation times. During experiment 9 , observations were conducted at all six daylight times.

No consistent substrate preference was seen. In the sand-gravel comparisons, one juvenile and one adult made no selection and the rest of the fish preferred whichever substrate was downstream (Figure 3). When sand was tested against boulder with cobble, both juveniles hid under the boulders more than $90 \%$ of the time. When cobble was removed to increase the sizes of interstitial spaces among boulders, three of four adults spent more than $65 \%$ of their time under the boulders. The other adult preferred sand, but hid under boulders about $14 \%$ of the time. In sand-gravel experiments, fish tended to choose downstream substrates. This may partly explain the preference for sand in the sand-boulder with cobble experiments. No clear preference occurred for substrate unless the substrate provided cover. Current speeds selected were similar to those depicted for the slow current in the current selection experiments (see Figure 2).

\section{Cover Selection}

To determine the features of overhead cover most important to smallmouth bass, we compared different covers that would provide, singly or in combination, tactile stimulation, a visual reference point, an area of quiet water, or an area of darkness (Tables 1, 2, experiments 12-17). Because we detected no preference by smallmouth bass for a specific substrate size if it did not itself provide cover, we used gravel in these experiments. Fast current speeds were used because they provided the variations in velocity necessary for comparing cover use in slow and fast currents.

Clear, flat, $900-\mathrm{cm}^{2}$ plates at the surface provided only tactile stimulation. If smallmouth bass shifted their depth preference to the surface under this cover, then tactile stimulation would be considered important. Low use of this cover, however, does not imply that tactile stimulation is unimportant; alternative sources, i.e., tank sides and corners, could provide superior tactile stimuli. Opaque, flat covers at the surface provided an area of darkness, a visual reference point, and tactile stimulation. When these covers were lowered to middepth, light intensity under the opaque cover decreased; all other variables remained the same. Open-ended boxes (open end downstream) provided areas of slow current and, when opaque, of low light intensity. For boxes, fast and slow current speeds refer to the current around, not inside, the box.

Covers were placed $50 \mathrm{~cm}$ from each end of the tank, $40 \mathrm{~cm}$ from the outer wall, and $20 \mathrm{~cm}$ from the inner partition. These two positions had distinctly different current speeds in the bottom 10 cm (Table 2)-upstream covers were surrounded by slower currents than downstream covers-and rarely were used when no cover was present. Clear and opaque covers of each type were tested simultaneously, one in each of these two positions. Flat overhead covers were tested first. Fish were acclimated for $3 \mathrm{~d}$ in the tank, then tested $1 \mathrm{~d}$ (all eight observation periods). The covers were then switched from one end to the other end of the tank or lowered. After each adjustment, we allowed 1 $d$ of acclimation and made observations on the following day. Fish were removed from the tank 
TABLE 2.-Summary of cover conditions for cover selection experiments with smallmouth bass in a laboratory stream tank.

\begin{tabular}{|c|c|c|c|c|c|c|}
\hline $\begin{array}{c}\text { Experi- } \\
\text { ment } \\
\text { number }\end{array}$ & Cover design & Depth & Type & Position & $\begin{array}{l}\text { Bottom cur- } \\
\text { rent velocity } \\
(\mathrm{cm} / \mathrm{s})\end{array}$ & $\begin{array}{l}\text { Light intensity } \\
\text { under covers } \\
\text { (lx) }\end{array}$ \\
\hline 12 & $\begin{array}{l}\text { Flat } \\
\text { Flat }\end{array}$ & $\begin{array}{l}\text { Surface } \\
\text { Surface }\end{array}$ & $\begin{array}{l}\text { Opaque } \\
\text { Clear }\end{array}$ & $\begin{array}{l}\text { Upstream } \\
\text { Downstream }\end{array}$ & $\begin{array}{l}2-3 \\
7-19\end{array}$ & $\begin{array}{c}25-75 \\
120-140\end{array}$ \\
\hline 13 & $\begin{array}{l}\text { Flat } \\
\text { Flat }\end{array}$ & $\begin{array}{l}\text { Surface } \\
\text { Surface }\end{array}$ & $\begin{array}{l}\text { Opaque } \\
\text { Clear }\end{array}$ & $\begin{array}{l}\text { Downstream } \\
\text { Upstream }\end{array}$ & $\begin{array}{l}7-19 \\
2-3\end{array}$ & $\begin{array}{c}25-75 \\
120-140\end{array}$ \\
\hline 14 & $\begin{array}{l}\text { Flat } \\
\text { Flat }\end{array}$ & $\begin{array}{l}\text { Middepth } \\
\text { Middepth }\end{array}$ & $\begin{array}{l}\text { Opaque } \\
\text { Clear }\end{array}$ & $\begin{array}{l}\text { Upstream } \\
\text { Downstream }\end{array}$ & $\begin{array}{l}2-3 \\
7-19\end{array}$ & $\begin{array}{c}25-75 \\
120-140\end{array}$ \\
\hline 15 & $\begin{array}{l}\text { Flat } \\
\text { Flat }\end{array}$ & $\begin{array}{l}\text { Middepth } \\
\text { Middepth }\end{array}$ & $\begin{array}{l}\text { Opaque } \\
\text { Clear }\end{array}$ & $\begin{array}{l}\text { Downstream } \\
\text { Upstream }\end{array}$ & $\begin{array}{l}7-19 \\
2-3\end{array}$ & $\begin{array}{c}25-75 \\
120-140\end{array}$ \\
\hline 16 & $\begin{array}{l}\text { Open-ended } \\
\text { box }\end{array}$ & Bottom & Opaque & Upstream & $\begin{array}{c}3 \\
(2-4)^{a}\end{array}$ & $1-33$ \\
\hline & $\begin{array}{l}\text { Open-ended } \\
\text { box }\end{array}$ & Bottom & Clear & Downstream & $\begin{array}{l}3-5 \\
(8-21)^{\mathrm{a}}\end{array}$ & 130 \\
\hline \multirow[t]{2}{*}{17} & $\begin{array}{l}\text { Open-ended } \\
\text { box }\end{array}$ & Bottom & Opaque & Downstreaam & $\begin{array}{l}3-5 \\
(8-21)^{\mathrm{a}}\end{array}$ & 7 \\
\hline & $\begin{array}{l}\text { Open-ended } \\
\text { box }\end{array}$ & Bottom & Clear & Upstream & $\begin{array}{c}3 \\
(2-4)^{\mathrm{a}}\end{array}$ & 140 \\
\hline
\end{tabular}

a Values in parentheses are bottom velocities around the boxes.

only between the overhead cover and box experiments.

Flat overhead covers at the surface and clear ones at middepth were not preferred by any fish (Table 3). Opaque flat covers at middepth were not used by the juveniles, but they were used by the adults when the current was slow. The only cover used provided shade and was in quiet water; therefore, the type of tactile stimuli these covers provided seemingly was not important to smallmouth bass.

Opaque open-ended boxes surrounded by slow

TABLE 3.-Median percent time spent by smallmouth under various covers (experiments 12-17) at preferred light intensities in a laboratory stream tank. Current velocity (fast or slow) was that in the vicinity of covers (see Table 2). Sample sizes (number of fish) are in parentheses.

\begin{tabular}{|c|c|c|c|c|c|c|}
\hline \multirow{3}{*}{$\begin{array}{l}\text { Cur- } \\
\text { rent } \\
\text { veloc- } \\
\text { ity }\end{array}$} & \multicolumn{6}{|c|}{ Cover type } \\
\hline & \multicolumn{2}{|c|}{$\begin{array}{l}\text { Plate at } \\
\text { surface }\end{array}$} & \multicolumn{2}{|c|}{$\begin{array}{c}\text { Plate at } \\
\text { middepth }\end{array}$} & \multicolumn{2}{|c|}{$\begin{array}{c}\text { Open-ended } \\
\text { box on bottom }\end{array}$} \\
\hline & Clear & $\overline{\text { Opaque }}$ & Clear & $\overline{\text { Opaque }}$ & Clear & $\overline{\text { Opaque }}$ \\
\hline \multicolumn{7}{|c|}{ Juveniles } \\
\hline Fast & $\begin{array}{l}0.6 \\
(2)\end{array}$ & $\begin{array}{l}1.5 \\
(2)\end{array}$ & $\begin{array}{l}0.4 \\
(2)\end{array}$ & $\begin{array}{l}1.3 \\
(2)\end{array}$ & $\begin{array}{l}2.0 \\
(3)\end{array}$ & $\begin{array}{l}48.0 \\
(4)\end{array}$ \\
\hline Slow & $\begin{array}{l}0.0 \\
(2)\end{array}$ & $\begin{array}{l}1.5 \\
(2)\end{array}$ & $\begin{array}{l}0.4 \\
(2)\end{array}$ & $\begin{array}{l}2.1 \\
(2)\end{array}$ & $\begin{array}{l}15.1 \\
(4)\end{array}$ & $\begin{array}{l}77.9 \\
(3)\end{array}$ \\
\hline \multicolumn{7}{|c|}{ Adults } \\
\hline Fast & $\begin{array}{l}0.0 \\
(2)\end{array}$ & $\begin{array}{l}0.9 \\
(2)\end{array}$ & $\begin{array}{l}0.0 \\
(2)\end{array}$ & $\begin{array}{l}0.6 \\
(2)\end{array}$ & $\begin{array}{l}0.4 \\
(4)\end{array}$ & $\begin{array}{l}48.3 \\
(4)\end{array}$ \\
\hline Slow & $\begin{array}{l}0.0 \\
(2)\end{array}$ & $\begin{array}{l}5.0 \\
(2)\end{array}$ & $\begin{array}{l}0.6 \\
(2)\end{array}$ & $\begin{array}{l}26.7 \\
\text { (2) }\end{array}$ & $\begin{array}{l}1.6 \\
(4)\end{array}$ & $\begin{array}{l}72.4 \\
(4)\end{array}$ \\
\hline
\end{tabular}

current $(2-4 \mathrm{~cm} / \mathrm{s})$ and located upstream were used more than any other box, greater than $65 \%$ of the time by all fish, except one adult that consistently avoided all cover (Table 3 ). This cover provided quiet water and low light. Clear boxes surrounded by fast current and located downstream rarely were used. Use of the other boxes, opaque boxes in fast water and clear boxes in slow water, varied among individuals, but were used less frequently than opaque boxes in slow water. Fish seemed to have trouble crossing the fast current to get to downstream boxes; several fish were swept against the downstream screen as they attempted to enter boxes. This was a factor in the reduced use of downstream (fast water) boxes. Thus, in these experiments, low light intensity and slow current influenced use of physical structure of both adult and juvenile smallmouth bass.

\section{Discussion}

Of the four physical factors examined, light intensity, current speed, and cover all influenced habitat selection by juvenile and adult smallmouth bass. Substrate, unless large enough to provide shelter, did not appear to influence position choice. Plexiglass covers seemed to have the greatest influence on habitat choice, especially when they provided slow current and reduced light.

Results from our study were consistent with other laboratory work with juvenile and yearling smallmouth bass (Klauda 1968; Haines and Butler 1969; Munther 1970; Reynolds and Casterlin 1976; MacCrimmon and Robbins 1981). In all these 
studies, smallmouth bass chose areas of slow current and darkness. Munther (1970) found that juvenile smallmouth bass in tanks preferred boulder substrates with large crevices to sand substrate, and, as in our study, fish hid beneath the boulders.

Our results were less consistent with results of various field investigations (Reynolds 1965; Munther 1970; Hubert 1981; Paragamian 1981; Probst et al. 1984; Rankin 1986). Although most of these studies indicate a preference by smallmouth bass for areas of reduced current, they have also illustrated some association between smallmouth bass and gravel or rocky substrate. Smallmouth bass spend more time feeding over gravel and cobble substrates than sand substrates (Rankin 1986). This suggests that substrate preferences may be partly food-related. The lack of prey in our experiments would then explain the lack of substrate preferences by fish in the laboratory.

Fish were more variable in their selection of current velocities during fast-current experiments than during slow-current experiments for both juveniles and adults. As the availability of slowcurrent areas decreases, fish must move through more areas of fast current just to reach patches with slow current; thus, the metabolic cost of living in a high-gradient area may be high even if much time is spent in slow current.

Because smallmouth bass exhibited distinct habitat preferences, we expect that the availability of preferred habitats could have a profound effect on habitat use. In the laboratory, smallmouth bass distribution seemed to be most strongly affected by cover and it is important in the field as well (Probst et al. 1984). Loss of cover in streams should have deleterious effects on smallmouth bass. In the process of stream channelization, habitat diversity is greatly reduced, and cover types such as undercut banks and overhanging vegetation are often eliminated. When cover availability is reduced in this manner, smallmouth bass populations decrease and growth usually slows (Griswold et al. 1978). Angermeier and Karr (1984) provide evidence that the removal of woody debris from a warmwater stream causes large fish to avoid these reaches. Although it seems evident that cover is important to smallmouth bass and large-scale destruction of habitat affects their populations, the relationship between the characteristics of cover and population size or growth has not been examined in the field.

If use of cover is feeding-related, i.e., smallmouth bass feed in or near cover or ambush prey from cover, then prey distribution may affect cov- er use. In an Ozark stream, where only $31 \%$ of smallmouth bass were in open water $(>1 \mathrm{~m}$ from cover), smallmouth bass fed primarily on crayfish and fish; benthic insects were much less important (Probst et al. 1984). In a Michigan stream, however, smallmouth bass less than $20 \mathrm{~cm}$ were typically observed foraging on benthic insects and rarely attacked crayfish or fish (based on daylight observations); in this stream smallmouth bass were seldom seen near cover (Rankin 1986). It is not known whether prey distribution affects cover use or if the availability of cover in a stream determines the foraging behavior of smallmouth bass. In the laboratory, selection of cover in the absence of prey suggests that the areas of slow current and darkness provided by physical structure could serve as resting areas: safe habitats with low metabolic cost.

\section{Acknowledgments}

We thank Vanessa Murchake, Jay Hafner, and Cathy Mitchell for their help with behavioral observations and Brian Goodman for the computer programs he wrote. P. Eschmeyer, K. D. Fausch, G. Helfman, K. Laub, J. Miner, and an anonymous reviewer made many useful comments on this paper. This work was supported by the Office of Water Research and Technology, U.S. Department of the Interior (A-058-Ohio).

\section{References}

Angermeier, P. L., and J. R. Karr. 1984. Relationships between woody debris and fish habitat in a small warmwater stream. Transactions of the American Fisheries Society 113:716-726.

Butler, R. L., and V. M. Hawthorne. 1968. The reactions of dominant trout to changes in overhead artificial cover. Transactions of the American Fisheries Society 97:37-41.

Coble, D. 1975. Smallmouth bass. Pages 21-31 in H. Clepper, editor. Black bass, biology and management. Sport Fishing Institute, Washington, D.C.

DeVore, P. W., and R. J. White. 1978. Daytime responses of brown trout (Salmo trutta) to cover stimuli in stream channels. Transactions of the American Fisheries Society 107:763-771.

Griswold, B. J., C. Edwards, L. Woods, and E. Weber. 1978. Some effects of stream channelization on fish populations, macroinvertebrates, and fishing in Ohio and Indiana. U.S. Fish and Wildlife Service Biological Services Program FWS/OBS-77.46.

Haines, T. A., and R. L. Butler. 1969. Responses of yearling smallmouth bass (Micropterus dolomieui) to artificial shelter in a stream aquarium. Journal of the Fisheries Research Board of Canada 26:21-31.

Hollander, M., and D. A. Wolfe. 1973. Nonparametric statistical methods. John Wiley and Sons, New York. 
Hubbs, C., and R. M. Bailey. 1938. The smallmouth bass. Cranbrook Institute of Science Bulletin 10.

Hubert, W. 1981. Spring movements of smallmouth bass in the Wilson Dam tailwater, Alabama. Journal of the Tennessee Academy of Science 56:105-106.

Hunt, R. L. 1976. A long-term evaluation of trout habitat development and its relation to improving management related research. Transactions of the American Fisheries Society 105:361-364.

Hurlbert, S. H. 1984. Pseudoreplication and the design of ecological field experiments. Ecological Monographs 54:187-211.

Klauda, R. J. 1968. The utilization of artificial shelter by yearling smallmouth bass (Micropterus dolomieui) in a stream aquarium as related to water hardness, temperature, and substrate. Master's thesis. Pennsylvania State University, University Park.

MacCrimmon, H. R., and W. H. Robbins. 1981. Influence of temperature, water current, illumination, and time on activity and substrate selection in juvenile smallmouth bass (Micropterus dolomieui). Canadian Journal of Zoology 59:2322-2330.

Moyle, P. B., and B. Vondracek. 1985. Persistence and structure of the fish assemblage in a small California stream. Ecology 66:1-13.

Munther, G. L. 1970. Movement and distribution of smallmouth bass in the Middle Snake River. Transactions of the American Fisheries Society 99:44-53.

Paragamian, V. L. 1981. Some habitat characteristics that affect abundance and winter survival of smallmouth bass in the Maquoketa River, Iowa. Pages
45-53 in L. A. Krumholz, editor. The warmwater streams symposium. Southern Division, American Fisheries Society, Bethesda.

Paragamian, V. L., and D. W. Coble. 1975. Vital statistics of smallmouth bass in two Wisconsin rivers, and other waters. Journal of Wildlife Management 39:201-210.

Probst, W. E., C. F. Rabeni, W. G. Covington, and W. E. Marteney. 1984. Resource use by stream-dwelling rock bass and smallmouth bass. Transactions of the American Fisheries Society 113:283-294.

Rankin, E. T. 1986. Habitat selection by smallmouth bass in response to physical characteristics in a natural stream. Transactions of the American Fisheries Society 115:322-334.

Reynolds, J. B. 1965. Life history of smallmouth bass, Micropterus dolomieui Lacepede, in the Des Moines River, Boone County, Iowa. Iowa State Journal of Sciences 39:417-436.

Reynolds, W. W., and M. E. Casterlin. 1976. Activity rhythms and light intensity preferences of Micropterus salmoides and $M$. dolomieui. Transactions of the American Fisheries Society 105:400-403.

Sale, P. F. 1972. Influence of corals in the dispersion of the pomacentrid fish, Dascyllus arvanus. Ecology 53:741-744.

Sechnick, C. W. 1981. Microhabitat selection by smallmouth bass in a simulated stream environment. Master's thesis, Ohio State University, Columbus.

Received November 30, 1984 Accepted December 28, 1985 